\title{
APPLICATION OF HEALTH BELIEF MODEL ON FACTORS INFLUENCING THE USE OF PERSONAL PROTECTIVE EQUIPMENT
}

\author{
Ristamaya Danar Dewi'), Setyo Sri Rahardjo²), Bhisma Murti') \\ ${ }^{1)}$ Masters Program in Public Health, Universitas Sebelas Maret \\ 2)Faculty of Medicine, Universitas Sebelas Maret
}

\begin{abstract}
Background: Personal protective equipment (PPE) is important to maintain a safe work environment and eliminate any potential hazards. The construction industry is one of the largest industries in any given society with many challenges of health and safety risks at the site. Construction workers face these risks because of exposure throughout the building process. This study aimed to determine factors influencing the use of PPE using Health Belief Model (HBM).

Subjects and Method: A cross sectional study was conducted at New Yogyakarta International Airport, Kulon Progo, Yogyakarta, in March 2019. A sample of 200 workers was selected by proportional random sampling. The dependent variable was the use of PPE. The independent variables were age, education, work experience, knowledge, perceived susceptibility, perceived benefit, perceived severity, and cues to action. The data were collected by questionnaire and analyzed by a multiple logistic regression. Results: The use of PPE was directly and positively affected by good knowledge (OR= 4.13; $95 \% \mathrm{CI}=1.1$ to $12.96 ; \mathrm{p}=0.015)$, strong perceived susceptibility (OR= 4.85; $95 \% \mathrm{CI}=1.26$ to $18.60 ; \mathrm{p}=0.021)$, perceived severity $(\mathrm{OR}=4.24 ; 95 \% \mathrm{CI}=1.27$ to 14.12 ; $\mathrm{p}=0.019)$, perceived benefit $(\mathrm{OR}=8.58 ; 95 \% \mathrm{CI}=2.63$ to $27.98 ; \mathrm{p}<0.001)$, cues to action $(\mathrm{OR}=7.17 ; 95 \% \mathrm{CI}=2.17$ to $23.62 ; \mathrm{p}=0.001)$, age $\geq 30$ years $(\mathrm{OR}=7.54 ; 95 \% \mathrm{CI}=$ 2.28 to $24.93 ; \mathrm{p}=0.001)$, work experience $>2$ years $(\mathrm{OR}=9.16 ; 95 \% \mathrm{CI}=2.51$ to 33.42 ; $\mathrm{p}=0.001)$, and education $\geq$ junior high school $(\mathrm{OR}=14.9 ; 95 \% \mathrm{CI}=3.63$ to 56.93 ; $\mathrm{p}<0.001)$.
\end{abstract}

Conclusion: The use of PPE is directly and positively affected by good knowledge, strong perceived susceptibility, perceived severity, perceived benefit, cues to action, age, work experience $>2$ years, and education $\geq$ junior high school.

Keywords: personal protective equipment, construction workers, health belief model

\section{Correspondence:}

Ristamaya Danar Dewi. Masters Program in Public Health, Univeritas Sebelas Maret. Jl. Ir. Sutami 36 A, Surakarta 57126, Jawa Tengah. Email: ristamayadd@gmail.com. Mobile: 082131666953. 